\title{
Costa, Walter Carlos; Tavares, Pedro Heliodoro; Rossi, Emi- liano de Brito (Orgs.). Psicanálise entre línguas. Rio de Janeiro: 7 Letras, 2016, 192 p.
}

Lia Martins ${ }^{1}$

${ }^{1}$ Universidade Federal do Ceará, Fortaleza, Ceará, Brasil.

Profundas e vastas são as interseções entre a psicanálise e os estudos da tradução. Sob um viés estrutural, é sabido que Freud considerava a interpretação dos sonhos como a tradução de uma língua estrangeira, entendimento que toma forma e se cristaliza sobretudo em Lacan, com sua formulação de que o inconsciente é estruturado como uma linguagem; assim, a tradução se estabelece com uma metáfora para o processo analítico, isto é, para a própria psicanálise.

Sob um viés pragmático, a difusão intercontinental alcançada pela psicanálise - aliada ao caráter migrante que cedo adquiriu em razão de sua subversividade radical - contribuiu para que suas obras fundamentais recebessem sucessivas, múltiplas traduções, e para que alguns dos mais importantes desenvolvimentos na clínica e na teoria tenham se dado com base justamente em leituras dessas traduções.

É com o intuito de reunir reflexões sobre as consequências, possibilidades e impasses surgidos do trânsito da psicanálise entre os idiomas, explorando cada uma das confluências entre tradução e psicanálise, que surge a obra Psicanálise entre línguas. Coletânea de 13 artigos - sendo três deles em língua estrangeira: um em alemão e dois em francês - organizada pelos pesquisadores da Uni- 
versidade Federal de Santa Catarina (UFSC) Walter Carlos Costa, Pedro Heliodoro Tavares e Emiliano de Brito Rossi, o livro foi lançado em 2016, com 192 páginas, pela editora carioca 7 Letras.

A maior parte dos textos apresentados na obra é fruto dos III e IV Simpósios Tradução e Psicanálise, realizados entre 2013 e 2014 na Universidade Federal de Santa Catarina (UFSC). Essa série de eventos, por sua vez, está ligada ao projeto As novas versões brasileiras da obra de Sigmund Freud: adaptações e recriações estilístico-conceituais, iniciado em 2010 sob a coordenação de Walter Carlos Costa no Programa de Pós-Graduação em Estudos da Tradução (PGET/UFSC).

O conjunto de autores é constituído por professores, em sua quase totalidade pesquisadores da área de Estudos da Tradução. São eles, por ordem de aparição: Paulo Sérgio de Souza Jr., Maria Rita Salzano Moraes, Christian Dunker, Elizabeth Brose, Marcus Coelen, Marcelo Jacques de Moraes, Maurício Eugênio Maliska, Junia Barreto, Claire Gillie, Patricia Reuillard, Walter Carlos Costa, Ernani Chaves, Pedro Heliodoro Tavares e Luiz Alberto Hanns. Dos 15 autores, aproximadamente metade atua como psicanalistas, enquanto um pouco mais da metade atua como tradutores, havendo superposições. Formações em literatura e filosofia complementam o currículo do conjunto - currículo eminentemente interdisciplinar, tal como o são os próprios Estudos da Tradução e a Psicanálise.

Os 13 artigos de que se compõe a obra são divididos em duas seções: $O$ divã de Babel, que contempla sete textos de abordagem ampla acerca da Psicanálise em suas relações com as línguas e linguagens, e $A$ psicanálise de uma língua a outra, cujas seis contribuições estão mais diretamente ligadas a traduções de obras e conceitos psicanalíticos.

A mencionada presença de três artigos em língua estrangeira, sem que qualquer tradução seja oferecida, contribui para tornar a obra 
menos acessível - ainda que se trate dos idiomas em que as mais importantes obras psicanalíticas foram escritas - e mais semelhante, em estrutura, a uma revista que a um livro. Pesa contra a unidade da obra, também, a significativa irregularidade observada entre os textos, em especial no que concerne ao nível de compreensibilidade a não iniciados, mas também relativa à inscrição de cada artigo entre os dois eixos temáticos cuja interseção constitui o foco do livro - psicanálise e tradução.

O texto de Marcelo Jacques de Moraes, "Sobre a violência da relação tradutória”, ainda que interessantíssimo pelo prisma dos Estudos da Tradução, possui escassas ligações com a Psicanálise. A contribuição de Maurício Eugênio Maliska, "Psicanalista traidor? Pontuações a partir da prática psicanalítica”, ao contrário, não apresenta vinculação alguma com os Estudos da Tradução para além de seu ponto de partida, o ditado traduttore, traditore. Já o artigo de Junia Barreto, “A demanda 'silenciosa' de Pierre Rivière. Da autobiografia ao cinema”, parece situar-se num limbo indistinto de tênues relações com ambos os eixos temáticos, não ficando suficientemente claros para o leitor ou a leitora os motivos de sua inclusão na coletânea.

Entre os textos que encontram o esperado equilíbrio, destaca-se o artigo de Walter Carlos Costa, "Notas sobre três traduções do Seminário Livro 3 de Lacan”, por proporcionar um panorama geral das questões que cercam a tradução da psicanálise e, mais especificamente, de Lacan, em uma escrita que prima pela linguagem e estruturação acessíveis, ainda que trazendo um grande volume de dados e conclusões significativas. Destaca-se igualmente o texto de Ernani Chaves, "Tradução, ética e política", que tece um sofisticado inventário sociológico e historiográfico da tradução de Trieb em Freud em paralelo com Benjamin, explicitando a posição ética e política denotada pela escolha de pulsão em detrimento de instinto. Também é digno de nota o artigo que abre a coletânea, "Uma zona linguística franca: o psíquico”, de Paulo Sérgio de Souza Jr., um 
tanto menos acessível que os dois anteriormente comentados, e que adquire relevo justamente pelo exotismo decorrente da demonstração da vasta erudição de seu autor - versado em mais de dez línguas, entre elas mandarim e idiomas do leste europeu - ao abordar questões relativas aos reflexos da subjetividade ou do psiquismo nas línguas e vice-versa.

Assim, apesar de suas fragilidades, Psicanálise entre línguas vale como conjunto pelo panorama que oferece de pesquisas relacionadas, em maior ou menor medida, à Psicanálise e aos Estudos da Tradução - áreas essencialmente interdisciplinares e que têm, portanto, muito a ganhar com possibilidades de diálogo como essa, especialmente considerando que as obras sobre essa exata convergência de eixos temáticos ainda são relativamente escassas no cenário nacional.

\section{Referências}

Costa, Walter Carlos; Tavares, Pedro Heliodoro; Rossi, Emiliano de Brito (Orgs.). Psicanálise entre línguas. Rio de Janeiro: 7 Letras, 2016. 192 p.

Recebido em: 15/04/2019

Aceito em: 13/07/2019

Publicado em: Setembro de 2019

Lia Martins. E-mail: liabmartins@live.com.

ORCID: https://orcid.org/0000-0001-7083-0462

Cad. Trad., Florianópolis, v. 39, no 3, p. 363-366, set-dez, 2019. 